\title{
Le système traditionnel d'irrigation chez les arabes Ga'aliyin Taragma (Soudan)
}

Christian Delmet

\section{OpenEdition}

Édition électronique

URL : https://journals.openedition.org/tc/882

DOI : $10.4000 /$ tc. 882

ISSN : 1952-420X

Éditeur

Éditions de l'EHESS

Édition imprimée

Date de publication : 1 février 1987

ISSN : 0248-6016

Référence électronique

Christian Delmet, «Le système traditionnel d'irrigation chez les arabes Ga'aliyin Taragma (Soudan) », Techniques \& Culture [En ligne], 8 | 1987, mis en ligne le 23 janvier 2006, consulté le 29 septembre 2022. URL : http://journals.openedition.org/tc/882 ; DOI : https://doi.org/10.4000/tc.882

Ce document a été généré automatiquement le 29 septembre 2022

Tous droits réservés 
Le système traditionnel d'irrigation chez les arabes Ga'aliyin Taragma (Soudan)

Christian Delmet 